\title{
PENGUKUHAN INSTITUSI KELUARGA MELALUI KAWALAN TERHADAP PERCERAIAN: ANALISIS LITERATUR
}

\author{
Strengthening Family Institution Through the \\ Control of Divorce: A Review of the Literature
}

\author{
Ahmad Hariri Mohd Saad * \\ Raihanah Hj Azahari **
}

\begin{abstract}
The family institution is one of the basic principles in developing a community. The success and failure of the community largely depends on the family institution. A solid family institution ensures the development of a healthy community. A lot of research has been conducted that discussed the family institution and marriage in the form of dissertation writings, thesis, books or journal articles. There are also non-academic writings that discussed this matter, such as books and popular articles. Thus, this journal will look at the literature that discusses the ways to strengthen marriage through the prevention of divorce. The literature that was being reviewed in this journal tended to focus on the prediction of the outcome of a marriage or relationships in marriage rather than the process of developing the marriage. The review also showed that most of the researchers tend to put too much focus on identifying how a split
\end{abstract}

\footnotetext{
* Pelajar Sarjana, Jabatan Fiqh dan Usul, Akademi Pengajian Islam, Universiti Malaya, Kuala Lumpur, fidauwais@yahoo.com

** Prof. Madya, Jabatan Fiqh dan Usul, Akademi Pengajian Islam,Universiti Malaya, Kuala Lumpur, raihan@um.edu.my
} 
in the marriage could happen. As an alternative, this research needs to be done in order to identify the strengths in the family structure and units.

Keywords: Marriage, Divorce, Family, Strengthen, Control Mechanism

\section{PENDAHULUAN}

Perkahwinan merupakan pokok bermulanya sesebuah institusi keluarga. Perkahwinan adalah satu tanggungjawab dan amanah yang harus dipikul oleh pasangan yang berkahwin. Dalam Islam, pasangan yang berkahwin bukan sahaja memegang amanah Allah tetapi juga memegang amanah keluarga yang merestui perkahwinan mereka dan amanah pasangannya yang telah memilih mereka sebagai teman hidup. ${ }^{1}$ Perkahwinan mempunyai impak yang besar terhadap pembentukan keluarga. Berdasarkan data, kadar perceraian di Malaysia meningkat lebih dua kali ganda dalam tempoh 8 tahun, dari 20,916 dalam tahun 2004 kepada 47,740 dalam tahun 2012, (The Malay Mail, Kuala Lumpur, March 32014 ). Ini menunjukkan bahawa perkahwinan bukan satu tugas yang mudah. Untuk mewujudkan perkahwinan yang berlangsung panjang dan berkekalan terdapat pelbagai cabaran besar yang harus ditempuhi. Sehubungan itu, penulisan ini akan meninjau penulisan dan kajian yang telah dibuat mengenai institusi perkahwinan di samping mengenal pasti penulisan dan kajian mengenai pencegahan dan pengawalan terhadap perceraian.

Untuk mengenal pasti penulisan yang relevan untuk ulasan ini, istilah atau terma utama "keluarga", "perceraian" dan "keluarga rapuh" telah digunakan. Tetapi secara umumnya penulisan berkaitan pengukuhan institusi keluarga melalui kawalan terhadap perceraian agak sukar diperolehi.

1 'Abd al-Karīm Zaydān, al-Mufașșal fì Ahkām al-Mar'ah wa a-Bayt al-Muslim fì al-Syarī'ah al-Islämiyyah (Bayrūt: Mu'assasah alRisālah, 1993), 7 : 1-7, 


\section{PERKAHWINANDAN IMPAKDALAM PEMBENTUKKAN KELUARGA}

Terdapat banyak kajian yang menyentuh tentang institusi keluarga terutamanya kajian tentang perkahwina. Ia boleh didapati sama ada dalam bentuk penulisan disertasi, tesis, buku dan artikel daripada pelbagai bidang pengajian.

Lucas, seorang ahli sosiologi melihat perkahwinan sebagai satu institusi yang boleh mempunyai kedua-dua kesan negatif dan positif, bergantung kepada kualiti hubungan perkahwinan. Hasil penyelidikannya telah menunjukkan bahawa perkahwinan yang pincang akan merisikokan tahap kesihatan. Malah perkahwinan yang bermasalah juga secara tidak langsung akan memberi kesan negatif kepada pasangan, anak-anak dan komuniti. ${ }^{2}$

Ahli psikologis dan epidemiologis seperti Cunningham $(2006)^{3}$ Nor Ba'yah dan Antonia Bifulco (2011) ${ }^{4}$ mendapati bahawa perkahwinan juga mempunyai kesan ke atas kesihatan fizikal dan psikologi seseorang. Mereka berpendapat bahawa orang yang berkahwin mempunyai kesihatan fizikal dan psikologi yang lebih baik, usia yang lebih lanjut serta berada dalam keadaan yang gembira berbanding mereka yang belum berkahwin atau yang telah bercerai. ${ }^{5}$ Bevvino Bruce S. (2003) pula menunjukkan mereka yang telah berkahwin mendapat manfaat yang lebih baik berbanding dengan yang belum berkahwin yang mana manfaat tersebut lebih

2 Lucas, Richard E. “Time Does Not Heal All Wounds," Psychological Science 16, no. 12 (December 2005): 945-950.

3 Cunningham, Mick \& Arland Thornton, "The Influences of Parents' and Offsprings' Experience with Cohabitation, Marriage, and Divorce on Attitudes Toward Divorce in Young Adulthood," Journal of Divorce Remarriage 44, no. 1 (2006): 119-144.

4 Nor Ba'yah Abdul Kadir \& Antonia Bifulco, "Vulnerability, Life Events and Depression Amongst Moslem Malaysian Women: Comparing Those Married and Those Divorced or Separate," Soc Psychiatry Psychiatr Epidemiol 46, no. 9 (Sept. 2011): 853-862.

5 Wilson, C. M. \& Oswald, A. J. "How Does Marriage Affect Physical and Psychological Health? A Survey of the Longitudinal Evidence. Bonn, Germany", Institute for the Study of Labor, Disc. Paper (2005): 1619. 
banyak dirasai oleh golongan lelaki berbanding wanita. ${ }^{6}$ Kajian mendapati lelaki mendapat kesejahteraan psikologi dan kesihatan fizikal yang lebih baik berbanding wanita.

Kajian Zarinah, Rozumah dan Rojanah (2002), ${ }^{7}$ Raihanah, ${ }^{8}$ Nurzahidah $^{9}$ (2011), Nur Zahidah dan Raihanah (2011), ${ }^{10}$ Fatima, Ajmal, ${ }^{11}$ Gunnur (2012) ${ }^{12}$ pula menunjukkan beberapa faktor yang saling berkait dengan pembentukan sesuatu keluarga yang berjaya. Faktor-faktor berkenaan adalah seperti komitmen, pengiktirafan, saling menghormati dan kejujuran, tanggungjawab, tolak-ansur dan toleransi, tidak mementingkan diri sendiri, komunikasi, empati dan kepekaan, kasih sayang dan kemesraan, keupayaan mengurus krisis, konflik dan tekanan, persamaan amalan dalam agama, kepuasan, kompromi, kasih sayang, penjagaan, kepercayaan dan persefahaman, komunikasi serta nilai keagamaan. Walau bagaimanapun Schovanec, Barb dan Cameron Lee (2001), ${ }^{13}$ Maria dan Ajmal (2012), menegaskan bahawa kepentingan faktor-faktor

6 Bevvino, Deborah L. \& Bruce S. Sharkin, "Divorce Adjustment As A Function of Finding Meaning and Gender Differences," Journal of Divorce Remarriage 39, no. 3-4 (2003): 81-97.

7 Zarinah Arshat, Rozumah Baharudin \& Rojanah Kahar, "Tingkah Laku Keibubapaan Dan Penyesuaian Tingkah Laku Anak Dalam Keluarga Berisiko Di Luar Bandar" Pertanika J. Soc. Sci \& Hum. 10, no. 2 (Universiti Putra Malaysia Press, 2002): 165-178.

8 Raihanah Azahari, "Factors Contribute to Martial Problems Among Malay Muslim Women: A Case Study in Malaysia," Jurnal Syariah 16, no. 2 (2008): 245-268.

$9 \quad$ Nurzahidah Hj Jaapar, "Perkahwinan Campur dan Hubungannya dengan Kebahagiaan Keluarga: Kajian di Selangor” (Sarjana Syariah, Jabatan Fiqh dan Usul, Akademi Pengajian Islam, Universiti Malaya, 2011), iii.

10 Nur Zahidah Hj Jaapar \& Raihanah Hj Azahari, "Model Keluarga Bahagia Menurut Islam", Journal Syariah 8 (2011): 25-44.

11 Maria Fatima \& M. Asir Ajmal, "Happy Marriage: A Qualitative Study", Pakistan Journal of Social and Clinical Psychology 9, no. 2, (2012): 37-42.

12 Karakurt Gunnur, "Relationship Stability Through Lenses of Complexity", The American Journal of Family Therapy 40 (2012): 126-140.

13 Schovanec, Barb \& Cameron Lee, "Culture and Divorce." Journal of Divorce \& Remarriage 36, no. 1-2 (2001): 159-177. 
ini mungkin berbeza-beza dari individu ke individu dan juga dari budaya ke budaya. ${ }^{14}$

Kajian Adler-Baeder, Brian dan Leanne Lamke (2004) menjelaskan terdapat pelbagai konsep yang dikaitkan dengan perkahwinan yang berkualiti antaranya adalah kebahagiaan, kesejahteraan, kepuasan dan kestabilan bagi sesuatu hubungan suami isteri. Penyelidik lain pula menyatakan perkahwinan berkualiti mempunyai kaitan dengan pengaruh tertentu seperti pengurusan konflik (Amato dan Denise Previti), ${ }^{16}$ komunikasi, (Aziyah) $)^{17}$ agama, (Kieran) ${ }^{18}$ kerjaya suami isteri, (Joän $)^{19}$ faktor ekonomi, (Hamidah) ${ }^{20}$ tekanan, (Halford, Charles Farrugia, Alf Lizzio dan Keithia Wilson) ${ }^{21}$ kelahiran anak dalam perkahwinan

14 Maria Fatima \& M. Asir Ajmal, "Happy Marriage”, 37-42.

15 Adler-Baeder, Francesca, Brian Higginbotham \& Leanne Lamke, "Putting Empirical Knowledge to Work: Linking Research and Programming on Marital Quality," Family Relations 53, no. 5 (October 2004): 537-546.

16 Amato, Paul R. \& Denise Previti. "People's Reasons for Divorcing: Gender, Social Class, The Life Course and Adjustment", Journal of Family Issues 24, no. 5 (July 1, 2003): 602-626.

17 Aziyah Abu Bakar "Relationships between Family Communication Patterns with Parenting Style and Family Cohesiveness" (Degree of Master of Science Universiti Putra Malaysia. 2008), 120.

18 Kieran T. Sullivan, "Understanding the Relationship Between Religiosity and Marriage: An Investigation of the Immediate and Longitudinal Effects of Religiosity on Newlywed Couple s," Journal of Family Psychology 15, no. 4 (2001): 610-626.

19 Joän M. Patterson. "Integrating Family Resilience and Family Stress Theory", Journal of Marriage and Family 64, http://www.jstor.org (May 2002): 349-360.

20 Hamidah Abd Rahman, "Faktor Penyumbang kepada Masalah Keluarga Tunggal dan Perceraian: Kajian Kes di Johor Darul Takzim," dalam Isu-isu Sosial (Johor, Skudai: Universiti Teknologi Malaysia, 2008): 23..

21 Halford, W. Kim, Charles Farrugia, Alf Lizzio \& Keithia Wilson, "Relationship Aggression, Violence and Self-regulation in Australian Newlywed Couples," Australian Journal of Psychology 62, no. 2 (July 2010): 82-92. 
(Polomeno, V.) ${ }^{22}$ dan faktor pendidikan (Adler-Baeder, Jennifer L. Kerpelman, Schramm, Higginbotham dan Paulk). ${ }^{23}$

Selain cuba untuk mengenal pasti risiko perkahwinan dan faktor kestabilan sesebuah perkahwinan, sarjana dalam bidang kekeluargaan juga telah mengemukakan beberapa kaedah dalam mengukuhkan perkahwinan. Contohnya Stahmann, R. $\mathrm{F}^{24}$ menjelaskan bahawa terdapat dua kaedah utama yang sering digunakan dalam mengukuhkan perkahwinan iaitu melalui pendidikan dan kaunseling. Di antara bidang yang menjadi fokus utama intervensi perkahwinan termasuklah komunikasi, penyelesaian konflik, peranan dan tanggungjawab, perhubungan seksual, kewangan, hubungan kekeluargaan, keibubapaan serta nilai keagamaan. ${ }^{25}$

Carrol \& Doherty (2003), ${ }^{26}$ Ruhil Hayati (2011) ${ }^{27}$ pula melihat intervensi pra perkahwinan seperti memberikan kaunseling dan pendidikan sebelum seseorang itu berkahwin sangat berkesan dalam membantu pasangan yang akan berkahwin dalam pelbagai aspek. Antaranya termasuklah meningkatkan kemahiran interpersonal dan kualiti perhubungan, mengurangkan masalah komunikasi yang boleh menjurus kepada masalah dalam hubungan

22 Polomeno, V., “ Marriage, Parenthood and Divorce: Understanding The Past as We Move into The Future", (1999): 13-20.

23 Francesca Adler-Baeder, Jennifer L. Kerpelman, David G. Schramm, Brian Higginbotham \& Amber Paulk. "The Impact of Relationship Education on Adolescents of Diverse Backgrounds." Family Relations 56, no. 3 (July 2007): 291-303.

24 Stahmann R. F., “Approaches to Marital Preparation for First Marriages and Remarriages in The USA." Paper Presented at The Prague Family Conference, Prague (1997): 1.

25 Stanley, SM, HJ Markman, Michelle St Peters \& BD Leber. "Strengthening Marriages and Preventing Divorce: New Directions in Prevention Research," Family Relations 44, no. 4 (1995): 392401.

26 Carrol, J. S. \& Doherty, W. J., "Evaluating The Effectiveness of Premarital Prevention Programs: A Meta-analytic Review of Outcome Research". Family Relation 52 (2003): 105-118.

27 Ruhil Hayati M. Busra, "Modul Kursus Pra Perkahwinan Islam: Kajian Terhadap Keberkesanannya di Jabatan Agama Islam Negeri Perak, Darul Ridzuan" (Disertasi Syariah, Jabatan Fiqh dan Usul, Akademi Pengajian Islam, Universiti Malaya, 2011). 
rumahtangga serta meningkatkan kualiti hidup pasangan tersebut kelak. $^{28}$

Carroll dan Doherty (2003) dalam kajian meta analisisnya juga menjelaskan bahawa dalam mengukuhkan perkahwinan ianya perlu dilakukan sebelum individu itu komited untuk berkahwin. Malah kajian juga mendapati melalui program pembangunan perkahwinan yang diwujudkan, secara purata individu yang terlibat dalam program pra perkahwinan secara signifikan lebih baik $70 \%$ dalam aspek kemahiran komunikasi, kemahiran pengurusan konflik, dan kualiti hubungan keseluruhannya, daripada individu yang tidak terlibat dengan program ini. Hasil kajian juga menunjukkan individu yang terlibat di dalam program ini mengalami 30\% peningkatan dalam ukuran kejayaan perhubungan. Daripada hasil jahian itu juga, Caroll dan Doherty (2003) merumuskan bahawa program pra perkahwinan secara umumnya adalah berkesan dalam meningkatkan kemahiran interpersonal dan kualiti perhubungan. Mereka turut menjelaskan sekurang-kurangnya berkesan ke atas peserta dalam tempoh enam bulan sehingga tiga tahun selepas peserta mengikuti program kemahiran tersebut. Ini kerana tidak terdapat banyak kajian (selepas tiga tahun) yang dibuat untuk membuat kesimpulan yang pasti tempoh keberkesanan program-program kemahiran tersebut. Mereka juga menegaskan walaupun program tersebut berkesan dalam jangka pendek, secara keseluruhannya peningkatan dalam aspek kemahiran interpersonal dan kualiti perhubungan secara signifikan adalah lebih baik bagi individu yang terlibat dalam program ini berbanding individu yang tidak terlibat. ${ }^{29}$

Kebanyakan kajian berkaitan pengukuhan perkahwinan menyimpulkan bahawa langkah pencegahan awal seperti program pendidikan pra perkahwinan, program kaunseling terbukti berkesan. Program yang berasaskan kemahiran dikatakan dapat membantu mengurangkan masalah perkahwinan yang tidak berfungsi melalui kaedah mengekalkan kemahiran. ${ }^{30}$ Contohnya

28 Ibid, 96-99.

29 Carrol, J. S. \& Doherty, W. J. "Evaluating the Effectiveness of Premarital Prevention Program," 105-118.

30 Michael Lane Morris \& Susan Alford Carter, "Transition to Marriage: A Litetature Review," Journal of Family and Consumer Sciences Education 17, no. 1 (Spring/Summer, 1999): 1-21. 
program "The Art of Loving Well" yang menekankan kemahiran sosial dan emosi, komunikasi yang berkesan, kemahiran berfikir secara kritis, kemahiran membuat keputusan dan kemahiran menghadapi konflik telah diuji keberkesanannya keatas perserta dalam kemahiran aspek tersebut yang secara posistif boleh dikaitkan dengan hasil perkahwinan yang baik. ${ }^{31}$

Manakala Risch, Riley dan Lawler ${ }^{32}$ (2003) pula mendapati pendidikan pra perkahwinan dan kaunseling membantu pasangan memperolehi maklumat tentang pelbagai aspek perkahwinan seperti membantu pasangan mengenalpasti aspek-aspek yang boleh mendatangkan masalah dalam kehidupan mereka kelak dan juga sumber-sumber yang dapat dirujuk apabila mengalami masalah rumah tangga. Malah hasil kajian juga mendapati program intervensi pra perkahwinan dapat mengurangkan tekanan dalam perkahwinan serta kadar perceraian. ${ }^{33}$

Secara keseluruhan berdasarkan tinjauan literatur yang dibuat, terdapat banyak kajian dan penulisan yang telah dibuat menyentuh tentang institusi keluarga yang sangat berkait rapat dengan perkahwinan. Ianya terlalu luas dan merangkumi pelbagai perspektif yang mencakupi pelbagai bidang pengajian.

\section{PERCERAIAN DAN IMPAK PERCERAIAN TERHADAP INSTITUSI KEKELUARGAAN}

Perceraian dan konflik merupakan satu isu yang sudah lama wujud dan sering diperkatakan dalam masyarakat. Perceraian juga turut menjadi topik utama kajian ilmiah dan penulisan artikel. Carian menggunakan Web Universiti Malaya iaitu Pendeta WebPAC ${ }^{34}$ pada Januari 2013 memaparkan sejumlah 9 disertasi dan tesis

31 Gardner S. P., K. Giese \& S. M. Parrott, "Evaluation of The Connections: Relationships and Marriage Curriculum," Family Relations 19, no. 1 (2004): 1-14.

32 Risch, G. A., Riley, L. A. \& Lawler, M. G., "Problematic Issues in The Early Years of Marriage: Content for Premarital Education", Journal of Psychology and Theology 31 (2003): 253-269.

33 Michael Lane Morris \& Susan Alford Carter, "Transition to Marriage", 1-21.

34 Pendeta WebPAC University of Malaya, http://www.pendeta.um.edu. my/ 
manakala dalam WEB OF SCIENCE ${ }^{35}$ sejumlah 1980 artikel yang disiarkan dalam jurnal sains sosial dan termasuk 2000 yang disenaraikan menjadikan perceraian sebagai topik utama penulisan. Memandangkan jumlah besar bahan yang diterbitkan, banyak kajian berkualiti tinggi yang dijalankan pada dekad yang lalu tidak dapat dimasukkan keseluruhannya dalam literatur ini.

Raihanah (1996), ${ }^{36}$ Mariam (2005) ${ }^{37}$ dan Norizan $(2008)^{38}$ melihat perceraian adalah berpunca daripada konflik, pengabaian tanggungjawab, penderaan dan penganiayaan. Perceraian selalu digunakan untuk menyelesaikan kemelut rumah tangga. Kajian ini lebih terfokus kepada peruntukan undang-undang mengenai bentuk-bentuk pembubaran perkahwinan dengan mencadangkan pemakaian dan pelaksanaan undang-undang yang lebih baik dalam menangani masalah berbangkit seperti mutu penghakiman dan prosedur perbicaraan dalam proses perceraian.

Amato, P. R. \& James, S. (2010), ${ }^{39}$ pula mengkaji perceraian yang berlaku di beberapa negara Eropah dan Amerika Syarikat dengan tumpuan kepada tiga aspek topik utama: (1) hubungan faktor demografi individu dengan perceraian, (2) kesan perceraian pada orang dewasa, dan (3) kesan perceraian terhadap kanakkanak. Dalam kajian ini mereka membuat kesimpulan bahawa perceraian mempunyai kesan dalam meningkatkan risiko pelbagai masalah kesihatan mental dan fizikal, kepada orang dewasa dan juga kanak-kanak. Walau bagaimanapun mereka mendapati faktor demografi seperti tahap ekonomi dan pendidikan adalah tidak konsisten dan berbeza-beza antara setiap negara kajian, faktor

\footnotetext{
35 Web of Science, http://pcs.webofknowledge.com/

36 Raihanah Hj Abdullah, "Alasan Membubarkan Perkahwinan Melalui Fasakh” Jurnal Syariah 5, no. 1 (1996): 1.

37 Mariam Rajwani Md. Nor, “Alasan Fasakh Nikah: Paksaan, Gila dan Kanak-kanak: Satu Kajian Perbandingan” (Tesis Master Universiti Kebangsaan Malaysia, 2005), iii.

38 Norizan Othman, "Kes Perceraian Secara Fasakh Kerana Darar di Mahkamah Syariah Melaka dari Tahun 1995-2000" (Disertasi Sarjana Syariah, Jabatan Syariah dan Undang-undang Universiti Malaya Kuala Lumpur, 2008), iii.

39 Amato, P. R. \& James, S., "Divorce in Europe and The United States: Commonalities and Differences Across Nations," Family Science 1, no. 1 (2010): 602-626.
} 
demografi tersebut boleh menjadi mempunyai kaitan positif di beberapa negara, tetapi mempunyai kaitan negatif dalam negara lain.

Terdapat beberapa kajian juga yang berbentuk tinjauan dilakukan terhadap bentuk-bentuk perceraian seperti kajian Rosmah $^{40}$ yang mengenal pasti prosedur pembubaran perkahwinan di Kelantan. Sofian ${ }^{41}$ membuat kajian mengenai kes perceraian luar mahkamah di mahkamah Syariah di Malaysia. Mohd. Zawawi ${ }^{42}$ yang mengkaji tentang syiq $\bar{a} q$ antara suami isteri dan cara penyelesaiannya menurut Islam. Kajian-kajian tersebut telah menilai prosedur undang-undang bagi setiap bentuk perceraian serta kaedah penyelesaiannya menurut syarak. Sementara kajian Yusida $^{43}$ dan Mazlan ${ }^{44}$ pula melihat perceraian diluar mahkamah dan kesannya mengikut undang-undang dan hukum syarak.

40 Che Rosmah Mohamed Zain, "Prosedur Perceraian di Mahkamah Syariah Negeri Kelantan" (Disertasi Sarjana Syariah, Jabatan Syariah dan Undang-undang, Akademi Pengajian Islam, Universiti Malaya, 2003), iii.

41 Sofian Ahmad, "Kajian Mengenai Kes Perceraian Luar Mahkamah di Mahkamah Syariah di Malaysia" (Tesis Sarjana Syariah, Universiti Kebangsaan Malaysia, 2005), iv.

42 Mohd. Zawawi Mat Amin, "Syiqaq Antara Suami Isteri dan Cara Penyelesaiannya Menurut Islam: Suatu Kajian di Unit Kaunseling di Jabatan Hal Ehwal Agama Islam Terengganu" (Disertasi Sarjana. Syariah), Jabatan Fiqh dan Usul, Akademi Pengajian Islam, Universiti Malaya, 2008,iii

43 Yusida Yusof, "Perceraian di Luar Mahkamah: Kajian di Mahkamah Syariah Wilayah Persekutuan Kuala Lumpur" (Disertasi Sarjana Syariah, Jabatan Syariah dan Undang-undang, Universiti Malaya, 2008), iv.

44 Mazlan Abd Manan, "Kesalahan-kesalahan Matrimoni dalam Kes Perceraian di Luar Mahkamah dan Tanpa Kebenaran Mahkamah: Kajian di Mahkamah Syariah Negeri Selangor Darul Ehsan" (Disertasi Sarjana Syariah, Jabatan Syariah dan Undang-undang, Akademi Pengajian Islam, Universiti Malaya, 2010), iii. 
Masnah, Mohd Zaki, Norhayati, Roslina dan Wan Mushida ${ }^{45}$ pula mengenal pasti hubungan antara pendapatan dengan peningkatan kadar perceraian dalam kalangan masyarakat Melayu di negeri Kelantan. Hasil kajian mereka menunjukkan terdapat hubungan yang signifikan di antara pendapatan dan kadar perceraian. Kajian mendapati mereka yang berpendapatan rendah merupakan golongan yang teramai terlibat dengan perceraian. Manakala Nor Dalilah ${ }^{46}$ dan Nor Dalilah dan Raihanah Azahari ${ }^{47}$ pula melihat konflik dalam rumah tangga dan hubungannya dengan perlaksanaan ibadat solat harian mendapati walaupun tidak terdapat hubungan yang signifikan antara perlaksanaan ibadat solat fardu dengan konflik dalam keluarga tetapi boleh dinyatakan bahawa lemahnya tahap pelaksanaan solat boleh membuka ruang kepada konflik rumah tangga.

Khairani ${ }^{48}$ pula yang mengkaji kesan perceraian ke atas akhlak remaja mendapati bahawa perceraian dan konflik dalam rumah tangga memberi kesan ke atas kehidupan remaja di sekolah

45 Masnah, Mohd Zaki, Norhayati \& Roslina Wan Mushida, "Kesan Pendapatan Ke Atas Kadar Perceraian di Kalangan Masyarakat Melayu di Negeri Kelantan," (Universiti Teknologi Mara, 2002): $1-15$.

46 Nor Dalilah Zakaria, "Perlaksanaan Ibadat Solat Hubungannya dengan Konflik Rumahtangga: Kajian di Unit Rundingcara Keluarga. Bahagian Perkahwinan dan Pembangunan Keluarga Jabatan Agama" (Sarjana Syariah, Jabatan Fiqh dan Usul, Akademi Pengajian Islam, Universiti Malaya, 2012).

47 Lihat juga, Nor Dalilah Zakaria \& Raihanah Azahari, Jurnal Syariah (2013): 145-164.

48 Khairani Zakariya, "Kesan Perceraian Terhadap Kehidupan Remaja: Suatu Kajian di Sekolah-sekolah Menengah Pulau Langkawi" (Disertasi Sarjana Usuluddin, Jabatan Sejarah dan Tamadun Islam Bahagian Pengajian Usuluddin, Akademi Pengajian Islam, Universiti Malaya, 2004), iv. 
menengah. Manakala Ros Asmaniza $^{49}$ dan Mahamatayuding ${ }^{50}$ yang membuat kajian mengenai hak undang-undang yang diguna pakai dan berpotensi melindungi hak-hak wanita selepas perceraian mendapati amalan dan peruntukan undang-undang tersebut berjaya memberikan perlindungan hak berbentuk kehartaan kepada wanita.

Terdapat juga kajian yang secara konsisten mengaitkan faktorfaktor sosio-demografi dengan risiko perceraian secara langsung dan tidak langsung (melalui kesannya kepada faktor-faktor perkahwinan). Antara ciri-ciri demografi yang sering dikaji oleh pengkaji yang lepas di pelbagai negara dalam mengenal pasti tren perceraian adalah seperti risiko perceraian dalam kalangan individu yang mengalami perceraian ibu bapa,${ }^{51}$ kemahiran intelektual dan pendidikan, ${ }^{52}$ penyertaan dalam tenaga buruh dalam kalangan wanita, ${ }^{53}$ usia perkahwinan dan umur pada masa perkahwinan. ${ }^{54}$ Penyelidik-penyelidik tersebut telah membuat beberapa andaian faktor yang mempunyai kaitan secara tidak langsung melalui kesannya kepada faktor demografi dengan perceraian yang telah

49 Ros Asmaniza Abdul Latif, "Mut'ah Talaq Sebagai Mekanisme Perlindungan Wanita Selepas Perceraian: Kajian Menurut Akta Undang-undang Keluarga Islam (Wilayah persekutuan) 1984 dan Perlaksanaannya" (Tesis (PhD), Akedemi Pengajian Islam, Jabatan Syariah dan Undang-undang, Universiti Malaya, 2013), iv.

50 Mahamatayuding Samah, "Tuntutan Selepas Perceraian Bagi Wanita Islam: Kajian Terhadap Amalannya di Tiga Wilayah Selatan Thai" (Tesis (PhD), Jabatan Syariah dan Undang-undang, Akademi Pengajian Islam, Universiti Malaya, 2011), iii.

51 Hartman, Laura R., Lilian Magalhães \& Angela Mandich, "What Does Parental Divorce or Marital Separation Mean for Adolescents? A Scoping Review of North American Literature," Journal of Divorce \& Remarriage 52, no. 7 (October 2011): 490-518.

52 Hamidah Abd Rahman, et. al, "Isu dan Faktor Keluarga Bermasalah di kalangan Orang Melayu: Kajian Kes di Negeri Johor Darul Takzim," dalam Isu-isu Sosial (Johor, Skudai: Universiti Teknologi Malaysia, 2008): 8.

53 Nomaguchi, K. M, "Marital Status, Gender and Home-to-Job Conflict Among Employed Parent," Journal of Family Issues 33, no. 3 (August 22, 2011): 271-294.

54 Amato, Paul R., "Research on Divorce: Continuing Trends and New Developments," (2010): 650-666. 
dipercayai menjejaskan kemampuan seseorang untuk menjalin dan mengekalkan hubungan dalam perkahwinan. Contohnya perceraian kalangan kelompok dikaitkan dengan kemungkinan terdapat kekurangan pengetahuan rumah tangga ketika memasuki alam perkahwinan, ketidak matangan emosi dan juga kekurangan penyelengaraan dan kebajikan dalam perkahwinan. ${ }^{55}$

Terdapat juga kajian yang mengukur kecenderungan sikap masyarakat apabila berhadapan dengan kesukaran dalam perkahwinan seperti kajian oleh Household, Income and Labour Dynamics in Australia (HILDA). Kajian ini mendapati bahawa lelaki lebih cenderung menolak perceraian sebagai penyelesaian kepada perkahwinan yang bermasalah berbanding dengan perempuan yang bersikap lebih menerimanya apabila menghadapi konflik dalam perkahwinan. Kajian tersebut turut mencadangkan pertimbangan semula dibuat terhadap undangundang yang mengetatkan peraturan perceraian, kerana ianya boleh menyukarkan individu yang mengalami konflik dalam perkahwinan membebaskan diri mereka daripada ikatan perkahwinan. ${ }^{56}$

Berdasarkan tinjauan literatur yang dibuat secara keseluruhannya, terdapat banyak kajian dan penulisan yang telah dibuat menyentuh tentang perceraian, ianya terlalu luas dan merangkumi pelbagai perspektif yang mencakupi pelbagai bidang pengajian dan terlalu sukar untuk dimasukkan keseluruhannya dalam penulisan ini.

\section{RUMUSAN DAN KESIMPULAN}

Berdasarkan bentuk dan corak penyelidikan yang dikaji, di dapati bahawa terdapat ruang yang luas bagi penyelidikan mengenai institusi keluarga, meskipun kajian yang ada telah melihat daripada pelbagai aspek dan perspektif, juga dalam pelbagai

55 Raihanah Azahari, "Permasalahan Rumah Tangga: Kajian Di Unit Undang-undang Keluarga Jabatan Agama Islam Daerah Petaling, Selangor," Jurnal Syariah 15, no. 1 (2007): 115-128.

56 Westo, Ruth, "Attitudes Towards Divorce," (Australian Insitute of Family Studies Relationship)s, Quarterly Issue, no. 11(2008): 1824. 
bidang pengajian. Penyelidikan mengenai kekeluargaan sepanjang dekad yang lalu telah memberi tumpuan kepada pelbagai topik termasuk perkahwinan dan perceraian. Antara perbincangan yang dilakukan mengenai topik perkahwinan dan pembentukkan keluarga adalah konsep perkahwinan, kualiti hubungan dan faktor yang saling berkait dengan pembentukan sesuatu keluarga yang berjaya. Sebilangan besar penyelidikan juga telah memberi tumpuan kepada intervensi untuk mengukuhkan perkahwinan terutamanya melalui pendidikan. Manakala, antara perbincangan yang menyentuh topik perceraian, adalah mengenai punca konflik, pemboleh ubah (variable) perceraian, hubungan antara perceraian dan kesejahteraan kanak-kanak dan bekas pasangan dan intervensi bagi mengawal perceraian. Walaupun terdapat kepelbagaian dalam kajian mengenai institusi keluarga dan nilai intrinsik hasil kajian, namun penyelidikan tersebut secara keseluruhannya tidaklah boleh dianggap sebagai menyumbang kepada pemahaman yang bersepadu tentang hubungan perkahwinan. ${ }^{57}$ Keseluruhan literatur yang terkumpul dalam penulisan ini dilihat cenderung untuk memberi tumpuan kepada ramalan mengenai hasil sesebuah perkahwinan atau hubungan perkahwinan dan bukannya kepada proses perkembangan perkahwinan. Satu kritikan terhadap penyelidikan yang dilakukan dalam bidang ini adalah kecenderungan penyelidik yang keterlaluan dalam mengenalpasti bagaimana keretakan hubungan perkahwinan berlaku. Sebagai alternatif, kajian juga perlu dilakukan untuk melihat kekuatan yang dimiliki dalam struktur dan unit keluarga.

\section{RUJUKAN}

'Abd al-Karīm Zaydān, al-Mufașșal fì Ahkām al-Mar'ah wa a-Bayt al-Muslim fì al-Syarī'ah al-Islämiyyah. Bayrūt: Mu'assasah al-Risālah, 1993.

Abdul Kadir, Nor Ba'yah \& Antonia Bifulco. "Vulnerability, Life Events and Depression Amongst Moslem Malaysian Women: Comparing Those Married and Those Divorced or Separated." Soc. Psychiatry and Psychiatric Epidemiology 46, no. 9 (Sept. 2011): 853-862.

57 Bradbury, T. N., Fincham, F. D. \& Beach, S. R. H, "Research On The Nature And Determinants Of Marital Satisfaction: A Decade In Review," Journal of Marriage and Family (2000): 459. 
Adler-Baeder, Francesca, Jennifer L. Kerpelman, David G. Schramm, Brian Higginbotham \& Amber Paulk. "The Impact of Relationship Education on Aolescents of Diverse Backgrounds." Family Relations 56, no. 3 (July 2007): 291 303.

Amato, P. R. \& James, S. "Divorce in Europe And The United States: Commonalities And Differences Across Nations". Family Science 1, no. 1 (2010): 602-626.

Amato, Paul R. \& Denise Previti. "People's Reasons For Divorcing: Gender, Social Class, The Life Course and Adjustment". Journal of Family Issues 24, no. 5 (July 1, 2003): 602-626.

Arshat, Zarinah, Rozumah Baharudin \& Rojanah Kahar. "Tingkah Laku Keibubapaan dan Penyesuaian Tingkah Laku Anak dalam Keluarga Berisiko di Luar Bandar." Pertanika J. Soc. Sci \& Hum. 10, no. 2 (Universiti Putra Malaysia Press, 2002): 165-178.

AziyahAbuBakar. "Relationships betweenFamily Communication Patterns with Parenting Style and Family Cohesiveness". (Tesis Sarjana Sains, Universiti Putra Malaysia, 2008).

Bevvino, Deborah L. dan Bruce S. Sharkin. "Divorce Adjustment As A Function of Finding Meaning and Gender Differences." Journal of Divorce Remarriage 39, no. 3-4 (2003): 81-97.

Carrol, J. S. \& Doherty, W. J. "Evaluating the Effectiveness of Premarital Prevention Programs: A Meta-analytic Review of Outcome Research". Family Relation 52 (2003): 105118.

Che Rosmah Mohamed Zain, "Prosedur perceraian di Mahkamah Syariah Negeri Kelantan" (Disertasi Sarjana Jabatan Syariah dan Undang-Undang, Akademi Pengajian Islam, Universiti Malaya, 2003).

Cunningham, Mick \& Arland Thornton. "The Influences of Parents' and Offsprings' Experience with Cohabitation, Marriage, and Divorce on Attitudes Toward Divorce in Young Adulthood." Journal of Divorce Remarriage 44, no. 1 (2006): 119-144. 
Fatima, Maria \& M. Asir Ajmal. "Happy Marriage: A Qualitative Study." Pakistan Journal of Social and Clinical Psychology 9, no. 2, (2012): 37-42.

Gardner, SP, K. Giese \& S. M. Parrott. "Evaluation of the Connections: Relationships and Marriage Curriculum*." Family Relations 19, no. 1 (2004): 1-14

Halford, W. Kim, Charles Farrugia, Alf Lizzio \& Keithia Wilson. "Relationship Aggression, Violence and Self-regulation in Australian Newlywed Couples." Australian Journal of Psychology 62, no. 2 (July 2010): 82-92.

Hamidah Abd Rahman. "Faktor Penyumbang kepada Masalah Keluarga Tunggal dan Perceraian: Kajian Kes di Johor Darul Takzim." Dalam Isu-isu Sosial (Johor, Skudai: Universiti Teknologi Malaysia, 2008): 23.

Hamidah Abd Rahman, et. al. "Isu dan Faktor Keluarga Bermasalah di kalangan Orang Melayu: Kajian Kes di Negeri Johor Darul Takzim." Dalam Isu-isu Sosial (Johor, Skudai: Universiti Teknologi Malaysia, 2008): 8.

Hartman, Laura R., Lilian Magalhães \& Angela Mandich. "What Does Parental Divorce or Marital Separation Mean for Adolescents? A Scoping Review of North American Literature." Journal of Divorce \& Remarriage 52, no. 7 (October 2011): 490-518.

Joän M. Patterson. "Integrating Family Resilience and Family Stress Theory". Journal of Marriage and Family 64 (May 2002): 349-360.

Karakurt, Gunnur. "Relationship Stability Through Lenses of Complexity": The American Journal of Family Theraphy 40 (2012): 126-140.

Kharani Zakariya. "Kesan perceraian terhadap kehidupan remaja suatu kajian di sekolah-sekolah menengah Pulau Langkawi". (Disertasi Sarjana Jabatan Sejarah Dan Tamadun Islam Akademi Pengajian Islam, Universiti Malaya, 2004).

Kieran T. Sullivan. "Understanding the Relationship Between Religiosity and Marriage: An Investigation of the Immediate and Longitudinal Effects of Religiosity on Newlywed 
Couples". Journal of Family Psychology 15, no. 4 (2001): 610-626.

Lucas, Richard E. "Time Does Not Heal All Wounds." Psychological Science 16, no. 12 (December 2005): 945950.

Mariam Rajwani Md. Nor. "Alasan Fasakh Nikah: Paksaan, Gila dan Kanak-kanak: Satu Kajian Perbandingan." (Tesis Sarjana Universiti Kebangsaan Malaysia, 2005).

Mahamatayuding Samah. "Tuntutan Selepas Perceraian bagi Wanita Islam: Kajian Terhadap Amalannya Di Tiga Wilayah Selatan Thai." (Tesis (PhD) Jabatan Syariah dan Undangundang, Akademi Pengajian Islam, Universiti Malaya, 2011).

Masnah, Mohd Zaki, Norhayati \& Roslina Wan Mushida. "Kesan Pendapatan ke atas Kadar Perceraian di Kalangan Masyarakat Melayu di Negeri Kelantan”. Laporan Akhir Penyelidikan, UITM, 2002.

Mazlan Abd Manan. "Kesalahan-kesalahan Matrimoni Dalam Kes Perceraian di Luar Mahkamah dan Tanpa Kebenaran Mahkamah: Kajian di Mahkamah Syariah Negeri Selangor Darul Ehsan." (Disertasi Sarjana Syariah, Jabatan Syariah dan Undang-undang, Akademi Pengajian Islam, Universiti Malaya, 2010).

Michael Lane Morris \& Susan Alford Carter. "Transition to Marriage: A Litetature Review." Journal of Family and Consumer Sciences Education 17, no. 1 (Spring/Summer, 1999).

Mohd. Zawawi Mat Amin. "Syiqaq antara Suami Isteri dan Cara Penyelesaiannya Menurut Islam: Suatu Kajian di Unit Kaunseling di Jabatan Hal Ehwal Agama Islam Terengganu”. (Disertasi Sarjana Syariah, Jabatan Fiqh dan Usul, Akademi Pengajian Islam, Universiti Malaya, 2008).

Mustonen, Ulla, Taina Huurre, Olli Kiviruusu, Ari Haukkala, \& Hillevi Aro. "Long-term Impact of Parental Divorce on Intimate Relationship Quality in Adulthood and the Mediating Role of Psychosocial Resources." Journal of 
Family Psychology 25, no. 4 (August, 2011).

Nor Dalilah Zakaria. "Perlaksanaan Ibadat Solat Hubungannya Dengan Konflik Rumah Tangga: Kajian di Unit Rundingcara Keluarga. Bahagian Perkahwinan dan Pembangunan Keluarga Jabatan Agama." (Disertasi Sarjana Syariah, Jabatan Fiqh dan Usul, Akademi Pengajian Islam, Universiti Malaya, 2012).

Nurzahidah Hj Jaapar \& Raihanah Hj Azahari. "Model Keluarga Bahagia Menurut Islam". Journal Fiqh, no. 8 (2011): 2544.

Nurzahidah Hj Jaapar. "Perkahwinan Campur dan Hubungannya dengan Kebahagiaan Keluarga: Kajian di Selangor". (Disertasi Sarjana, Jabatan Fiqh dan Usul, Akademi Pengajian Islam, Universiti Malaya, 2011).

Norizan Othman. "Kes Perceraian Secara Fasakh Kerana Darar di Mahkamah Syariah Melaka dari Tahun 1995-2000". (Disertasi Sarjana, Jabatan Syariah dan Undang-undang, Universiti Malaya, 2008).

Nomaguchi, K. M. "Marital Status, Gender, and Home-to-Job Conflict Among Employed Parents." Journal of Family Issues 33, no. 3 (August 22, 2011): 271-294.

Pendeta WebPAC University of Malaya, http://www.pendeta. um.edu.my/

Raihanah Azahari. "Factors Contribute to Martial Problems Among Malay Muslim Women: A Case Study in Malaysia." Jurnal Syariah 16, no. 2 (2008): 245-268.

Raihanah Azahari. "Permasalahan Rumah Tangga: Kajian Di Unit Undang-undang Keluarga Jabatan Agama Islam Daerah Petaling, Selangor". Jurnal Syariah 15, no.1 (2007): 115128.

Raihanah Haji Abdullah. "Alasan Membubarkan Perkahwinan Melalui Fasakh”. Jurnal Syariah 5, no. 1 (1996): 1.

Ros Asmaniza Abdul Latif. "Mut'ah Talaq Sebagai Mekanisme Perlindungan Wanita Selepas Perceraian: Kajian Menurut AktaUndang-Undang Keluarga Islam(WilayahPersekutuan) 
1984 dan Perlaksanaannya." (Tesis (PhD) Jabatan Syariah dan Undang-undang, Akedemi Pengajian Islam, Universiti Malaya, 2013).

Risch,G. A., Riley, L. A. \& Lawler, M. G. "Problematic Issues in the Early Years of Marriage: Content for Premarital Education". Journal of Psychology and Theology 31, (2003): 253-269.

Ruhil Hayati M. Busra. "Modul Kursus Praperkahwinan Islam: Kajian Terhadap Keberkesanannya di Jabatan Agama Islam Negeri Perak, Darul Ridzuan". (Disertasi Sarjana Jabatan Fiqh dan Usul, Akademi Pengajian Islam, Universiti Malaya, 2011).

Schovanec, Barb \& Cameron Lee. "Culture and Divorce." Journal of Divorce \& Remarriage 36, no. 1-2 (2001): 159-177.

Sofian Ahmad. "Kajian Mengenai Kes Perceraian Luar Mahkamah di Mahkamah Syariah di Malaysia." (Tesis Sarjana Syariah, Universiti Kebangsaan Malaysia, 2005).

Stahmann, R. F. "Approaches to Marital Preparation for First Marriages and Remarriages in the USA." Paper presented at the Prague Family Conference. (Prague, 1997): 1.

Stanley, SM, HJ Markman, Michelle St Peters \& BD Leber. "Strengthening Marriages and Preventing Divorce: New Directions in Prevention Research." Family Relations 44, no. 4 (1995): 392-401.

Web of Science, http://pcs.webofknowledge.com/

Westo, Ruth. "Attitudes Towards Divorce." Australian Insitute of Family Studies Relationships Quarterly Issue 11 (2008).

Wilson, C. M. \& Oswald, A. J. "How Does Marriage Affect Physical and Psychological Health? A Survey of The Longitudinal Evidence. Bonn, Germany", Institute for the Study of Labor, Disc. Paper, 2005.

Yusida Yusof. "Perceraian di luar Mahkamah: Kajian di Mahkamah Syariah Wilayah Persekutuan Kuala Kumpur. (Disertasi Sarjana Jabatan Syariah dan Undang-undang, Universiti Malaya, 2008. 
Jurnal Fiqh, No. 11 (2014) 175-194 